\title{
Hubungan antara Intelegensi Kemampuan Menyimak, dan Kemampuan Membaca, dengan Prestasi Belajar (Studi pada Siswa SMAN di Bandung)
}

\section{Oleh: Pien Supinah Adiwiria}

Abstrak: Studi ini bertujuan, untuk mengidentifikasi pengaruh intelegensi terhadap kemampuan menyimak dan kemampuan membaca, dan pengaruh intelegensi, kemampuan membaca, dan kemampuan menyimak terhadap prestasi belajar. Studi ini menggunakan sampel sebanyak 112 siswa SMA di kota Bandung. Studi ini menemukan pengaruh intelegensi. terhadap kemampuan menyimak dan kemampuan membaca. Hasil studi ini juga mengindikasikan pengaruh kemampuan membaca terhadap prestasi belajar serta pengaruh kemampuan menyimak terhadap prestasi belajar, juga mengindentifikasi pengaruh gabungan antara intelegensi, kemampuan menyimak, dan kemampuan membaca terhadap prestasi belajar. Studi ini menemukan suatu model sebab akibat dari hubungan intelegensi, kemampuan membaca, dan kemampuan menyimak terhadap prestasi belajar

Kata kunci: intelegensi, kemampuan menyimak, kemampuan membaca, prestasi belajar.

\section{Latar Belakang Masalah}

Permasalahan, yang sedang kita hadapi pada saat ini di antaranya adalah rendahnya prestasi belajar para siswa. Hal ini dibuktikan dari rendahnya Nilai Ujian Akhir Nasional (NUAN) siswa SMAN. Ujian Akhir
Nasional (UAN) merupakan puncak kegiatan proses belajar mengajar untuk mengetahui standar mutu pengetahuan dan kemampuan peserta didik dalam menyelesaikan program pendidikan di sekolah. Berdasarkan data faktual dari Dinas

\footnotetext{
* Pien Supinah Adiwira adalah dosen pada FPBS Universitas Pendidikan Indonesia Bandung
} 
Pendidikan Kota Bandung, rata-rata prestasi belajar siswa SMAN di kota Bandung dari mata pelajaran yang diuji secara nasional (UAN) untuk SMA IPA adalah 6,462 dan SMA IPS adalah 6,269 tahun ajaran 2004/2005.

Barker et.al (1980) dan Banks (1985) berpendapat bahwa prestasi belajar sangat dipengaruhi oleh kemampuan membaca dan kemampuan menyimak. Siswa yang berkemampuan menyimak dan berkemampuan kemampuan membacanya rendah, cenderung memiliki prestasi belajar yang rendah pula jika dibandingkan dengan siswa, yang memiliki kemampuan menyimak dan kemampuan membaca yang lebih tinggi. Barker et.al (1980) meneliti komposisi jumlah waktu yang dihabiskan siswa dalam proses belajar di kelas. Ia menemukan bahwa para siswa menghabiskan 53 persen waktunya untuk menyimak, 17 persen untuk membaca, 16 persen untuk berbicara dan 14 persen untuk menulis. Hal ini menunjukkan bahwa para siswa menghabiskan 70 persen waktunya untuk kegiatan menyimak dan kegiatan membaca dalam proses belajar di sekolah.

Beberapa penelitian lainnya (Johnson 2005; Strang 1968; Stanovich et.al 1984; Vineyard and Bailey 1960; Vineyard and Massey
1957) mengindikasikan adanya hubungan yang signifikan antara intelegensi dan kemampuan membaca. Studi ini juga mengidentifikasikan adanya hubungan yang signifikan antara intelegensi dengan kemampuan menyimak (Nichols 1948; Vineyard and Bailey 1960). Dengan menggunakan sampel sebanyak 144 orang siswa di Southwestern State College Amerika Serikat, Vinegard and Bailey (1960) mengenali hubungan antara intelegensi, membaca dan menyimak, dengan prestasi belajar. Mereka menemukan terdapat korelasi yang erat antara intelegensi, membaca dan menyimak, dengan prestasi belajar.

Dengan menggunakan sampel sebanyak 112 siswa SMAN di kota Bandung, studi ini bertujuan untuk mengidentifikasi pengaruh intelegensi terhadap kemampuan menyimak dan kemampuan membaca, dan pengaruh intelegensi, kemampuan menyimak dan kemampuan membaca terhadap prestasi belajar.

\section{Kajian Pustaka}

Menyimak dan membaca merupakan kegiatan yang paling dominan dalam proses belajar mengajar di sekolah. Barker et.al (1980) mengemukakan waktu yang paling banyak digunakan dalam proses belajar mengajar 
didominasi oleh komunikasi reseptif, yakni menyimak 53\%, dan membaca 17\%. Dwyer (1978) juga mengindikasikan hal yang sama, sebagian besar proses belajar dilakukan dengan menggunakan indera penglihatan sebesar $83 \%$, indera pendengaran sebesar $11 \%$, dan sisanya digunakan untuk indera lainnya, yakni indera penciuman $(3,5 \%)$, sentuhan $(1,5 \%)$, dan rasa (1\%). Berbagai temuan itu menunjukkan betapa penting dan dominan kedua kegiatan itu (menyimak dan membaca) dalam proses belajar mengajar.

Menyimak dan membaca merupakan kemampuan dasar manusia di dalam kehidupan sehari-hari, dan lebih utama lagi dalam proses belajar mengajar(Doman 1986; Tubbs 2000). Dalam kehidupan sehari-hari, manusia dapat terlibat baik secara aktif maupun secara pasif dalam pemerolehan bahasa dan pemerolehan informasi melalui menyimak dan membaca (Nida 1952). Dengan kata lain, seseorang tidak akan bertambah pengetahuannya apabila tidak melakukan kegiatan menyimak dan kegiatan membaca.

Intelegensi merupakan salah satu faktor penting dalam pengembangan kemampuan menyimak dan kemampuan membaca. Kita ambil sebuah contoh untuk memahami satu kalimat dalam kegiatan menyimak, diperlukan beberapa tahapan pemahaman dan intelegensi sangat dibutuhkan dalam hal itu (Maltin 1994). Tahapan tersebut meliputi mendengarkan suara simakan, menyimpan suara simakan tersebut ke dalam ingatan jangka pendek (short term memory), mencari makna kata dalam memori semantik, mengelompokkan maknanya setiap bunyi simakan, dan menemukan intisari dari pengelompokan tersebut untuk diambil maknanya.

Sebagai tambahan, intelegensi pun merupakan faktor yang menentukan kemampuan siswa dalam kegiatan membaca (Burmeister 1978: Maltin 1994; Strang 1968; Stanovich et.al 1984; Yap 1977). Burmeister (1978) juga menegaskan terdapat faktor lain yang menentukan kemampuan mambaca siswa yaitu tingkatan dan rentang minat, penyesuaian emosi, imajinasi siswa serta persepsi terhadap penglihatan dan pendengaran.

Beery (1954) menyatakan, proses membaca itu dipengaruhi oleh empat faktor, yakni faktor verbal mencakup interpretasi ide, faktor persepsi mencakup fasilitas dalam memahami detail, faktor kata melibatkan kemahiran dalam berurusan dengan kata, dan faktor 
yang terkait dengan organisasi logis dan seleksi ide-ide yang relevan

Kemampuan menyimak dan membaca juga ditentukan oleh berbagai faktor termasuk fasilitas belajar, kemampuan memahami isi pesan dan kemampuan mengolah informasi (Rixon 1981). Kemampuan kognitif, meliputi kemampuan mengingat, kemampuan memahami, kemampuan menerapkan, kemampuan menganalisis, kemampuan mensistesis dan kemampuan mengevaluasi, yang merupakan faktor penting dalam meningkatkan kemampuan menyimak dan membaca (Bloom 1974).

Berbagai penelitian telah dilakukan untuk mengetahui kemampuan menyimak dan membaca para siswa di Indonesia. Soegianto (1981) melakukan penelitian pada para siswa kelas enam sekolah dasar di Madura, dan menemukan hasil, para siswa dapat memahami keseluruhan bahan simakan hanya $62 \%$. Nursaid (1992) melakukan penelitian pada para siswa kelas empat dan lima di Purbalingga menemukan hasil, para siswa dapat memahami keseluruhan bahan simakan hanya $69 \%$. Heryadi (2001) meneliti kemampuan menyimak para siswa sekolah menengah pertama, dan menemukan hasil, para siswa dapat memahami keseluruhan bahan simakan hanya $25 \%$. Rusyana (1981) melakukan penelitian pada para siswa SPG di Jabar dan menemukan hasil, para siswa dapat memahami keseluruhan bahan simakan hanya $40 \%$. Adiwiria, Pien S (2002) meneliti kemampuan menyimak para siswa SMAN di Kota Bandung, dan menemukan hasil, para siswa dapat memahami keseluruhan bahan simakan hanya $65 \%$.

Tampubolon (1986) melakukan penelitian terhadap kecepatan membaca para siswa di Indonesia, dagn menemukan hasil, kecepatan membaca para siswa hanya tercapai 127,5 kata per menit dengan tingkat pemahamanan isi bacaan sebesar $60 \%$. Beberapa penelitian lainnya (Akil 1993; Haryanto 1999; Razak 1989) memperlihatkan hasil, ada perbedaan tingkat pemahaman para siswa terhadap isi bacaan. Akil (1993), Haryanto (1999) dan Razak (1989) menemukan hasil tingkat pemahaman para siswa terhadap isi bacaan, masing-masing memperoleh $67 \%$, $83 \%$ dan $50 \%$.

UNESCO (Moegiadi 1992) menyatakan bahwa kemampuan membaca para siswa di Indonesia sangatlah memprihatinkan. Indonesia menduduki rangking 30 dari 31 negara yang diteliti. Siswa-siswa Indonesia memiliki minat membaca 
rendah dibandingkan dengan siswasiswa di negara maju. Mulyana (2000) mengemukakan penyebab siswa bangsa asing memiliki minat baca tinggi karena mereka memiliki tradisi membaca yang baik; banyak buku yang terbit; harganya relatif murah; daya beli tinggi; serta perpustakaan bertebaran di mana-mana, di Indonesia sebaliknya. Ia menegaskan pula bahwa masyarakat Indonesia mempunyai budaya tutur dibandingkan dengan budaya menulis sehingga mereka cenderung tidak menyukai membaca.

Vineyard dan Bailey (1960) menemukan hubungan yang signifikan antara kemampuan menyimak dengan prestasi belajar. Mereka meneliti 114 orang siswa di Southwestern State College Amerika Serikat sebagai sampel, dan menemukan koefisien korelasi antara kemampuan menyimak dengan prestasi belajar sebesar 0,25 , dengan tingkat kepercayaan 0,01 . Nichols (1948) memperoleh hasil yang serupa, ia meneliti 200 orang mahasiswa baru pada tahun pertama di University of Minnesota Amerika Serikat dan menemukan koefisien korelasi antara kemampuan menyimak dengan prestasi belajar sebesar 0,28. Adiwiria, Pien S (2002) melakukan penelitian mengenai hubungan antara kemam- puan menyimak dengan prestasi belajar para siswa SMAN di Kota Bandung dengan menggunakan sampel sebanyak 112 orang siswa dari 2 SMAN yang berbeda. Ia menemukan koefisien korelasi sebesar 0,33 dengan tingkat kepercayaan 0,05.

Vineyard dan Massey (1957) mengindikasikan hubungan yang signifikan antara kemampuan membaca dengan prestasi belajar, dengan menggunakan sampel sebanyak 176 mahasiswa baru pada tahun pertama Panhandle Agricultural and Mechanical College di Amerika Serikat. Mereka menemukan koefisien korelasi antara kemampuan membaca dengan prestasi belajar sebesar 0,43. Vineyard dan Bailey (1960) juga menemukan koefisien korelasi antara kemampuan membaca dengan prestasi belajar sebesar 0,53 , dengan menggunakan sampel sebanyak 114 siswa di Southwestern State College.

Beberapa penelitian terhadap para siswa di Indonesia mengenai kemampuan membaca dengan prestasi belajar memperlihatkan, kemampuan membaca merupakan faktor utama, yang menentukan prestasi belajar ( Rosidi 1972; Haryanto 1999). Mereka menemukan adanya hubungan yang signifikan antara kemampuan membaca dengan prestasi belajar para siswa di Indonesia. 


\section{Metode Penelitian}

Desain penelitian yang digunakan dalam penelitian ini adalah explanatory survey. Penelitian survey bertujuan untuk mengembangkan maupun menguji kebenaran pengetahuan dengan melakukan pengujian terhadap hipotesishipotesis. Sampel penelitiaannya adalah siswa SMAN kelas III di kota Bandung. Penarikan sampel dilakukan dengan teknik Multy-stage Cluster Sampling. Proses perhitungan ukuran sampel dilakukan dengan berbagai tahapan. Hasil dari berbagai tahapan tersebut menghasilkan sejumlah sampel (112 responden). Studi ini berhipotesis bahwa siswa yang memiliki intelegensi tinggi lebih memiliki kemampuan menyimak dan kemampuan membaca yang tinggi pula. Studi ini berhipotesis juga bahwa makin tinggi intelegensi yang berasosiasi dengan kemampuan menyimak dan kemampuan membaca maka akan makin tinggi pula prestasi belajar siswa yang bersangkutan.

\subsection{Pengumpulan Data}

Sampel yang digunakan pada studi ini adalah para siswa SMAN di kota Bandung. Bandung sebagai kota terbesar kedua di Indonesia dengan populasi lebih dari 5 juta jiwa (2005), memiliki 26 SMAN. Pada studi ini, penarikan sampelnya dilakukan dengan teknik Multy-stage Cluster Sampling. Sampel terpilih secara acak sebanyak 7 SMAN. Setelah terpilih jumlah SMAN diambil lagi secara acak sampel dari masing-masing sekolah sebanyak 4 kelas III dan dari tiap-tiap kelas III terpilih diambil lagi sampel siwa secara acak sebanyak 4 orang siswa, sehingga jumlah responden untuk studi ini adalah sebesar 112 orang siswa yang terdiri dari 60 orang laki-laki dan 52 orang perempuan. Pengumpulan data dilakukan pada bulan April 2005 hingga Oktober 2005.

Variabel. Studi ini menggunakan intelegensi sebagai variabel bebas, kemampuan menyimak dan kemampuan membaca sebagai variabel antara, dan prestasi belajar sebagai variabel terikat.

Instrumen Survai. Untuk mengukur tingkat intelegensi para siswa, studi ini menggunakan tes Advance Progressive Matrices (APM). Tes tersebut diselenggarakan oleh Laboratorium Psikologi Pendidikan dan Bimbingan (LPPB) sebagai institusi yang berwenang untuk menyelenggarakannya, sedangkan untuk mengukur kemampuan menyimak para siswa, studi ini mengembangkan tes yang disam- 
paikan dalam bentuk tuturan yang diperdengarkan secara berjenjang pada tes aspek kognitif. Tes aspek kognitif secara berjenjang misalnya: ingatan, pemahaman, penerapan, analisis, sintesis dan evaluasi. Pada aspek ingatan, peserta tes hanya dituntut untuk mengingat fakta-fakta atau menyebutkan kembali fakta yang telah mereka simak. Pada aspek pemahaman, peserta tes diharapkan untuk memahami ujaran atau tuturan yang diperdengarkan, aspek ini dicapai melalui serangkaian aktivitas, seperti menghubung-hubungkan ide, faktor atau kejadian. Pada aspek penerapan, peserta tes diminta untuk menerapkan konsep atau masalah tertentu pada situasi tertentu pula. Pasda aspek analisis hampir sama dengan aspek pemahaman, perbedaannya hanya terletak pada aspek pemahamannya. Misalnya pada aspek analisis dituntut menganalisis mengenai detail-detail informasi, menemukan hubungan kelogisan, hubungan sebab akibat atau hubungan situasional. Pada aspek sintesis, peserta dituntut untuk mampu menghubungkan berbagai hal, konsep, masalah, atau pendapat, yang terdapat dalam ujaran yang diperdengarkan. Pada aspek evaluasi, peserta dituntut untuk memberikan penilaian terhadap tuturan yang diperdengarkan, baik penilaian mengenai gagasan, konsep, cara pemecahan masalah atau untuk menemukan/menilai bagaimana cara pemecahan masalah itu.

Untuk mengukur kemampuan membaca para siswa, studi ini mengembangkan tes yang disampaikan melalui bahasa tulis berupa wacana. Tes yang dilakukannya adalah aspek-aspek kognitif yang berjenjang, sama halnya seperti tes menyimak di atas. Tes tersebut terdiri dari pertanyaan-pertanyaan yang menyangkut ilmu pengetahuan dan teknologi. Tes aspek kognitif berjenjang dimulai dari aspek ingatan, pemahaman, penerapan, analisis, sintesis hingga evaluasi. Keenam aspek tersebut telah dijelaskan dalam tes menyimak ( bahasa tutur) seperti telah dijelaskan di atas. Kemudian, untuk mengukur prestasi belajar para siswa, studi ini menggunakan tiga pengukuran, yaitu nilai ujian akhir nasional, nilai ujian akhir sekolah, dan nilai rapor kelas tiga semester satu dan semester dua untuk tahun akademik 2004/2005.

\subsection{Analisis Data}

Intelegensi, kemampuan menyimak, kemampuan membaca, dan prestasi belajar dianalisis untuk mengidentifikasi pengaruh langsung intelegensi 
terhadap kemampuan menyimak, kemampuan membaca, dan untuk mengidentifikasi pengaruh gabungan antara intelegensi, kemampuan menyimak, dan kemampuan membaca terhadap prestasi belajar. Studi ini menggunakan path analysis $(\mathrm{Li}$, 1975) seperti terlihat pada Gambar 1.

Untuk mengidentifikasi pengaruh intelegensi terhadap kemampuan menyimak dan kemampuan membaca, studi ini menghitung Pzlx and Pz2x. Untuk mengidentifikasi pengaruh intelegensi, kemampuan menyimak dan kemampuan membaca, terhadap prestasi belajar, studi ini menggunakan koefisien determinasi R2.

\section{Hasil Penelitian}

\subsection{Profil Responden}

Intelegensi. Tes Advance Progressive Matrices (APM) adalah instrumen untuk mengukur tingkat

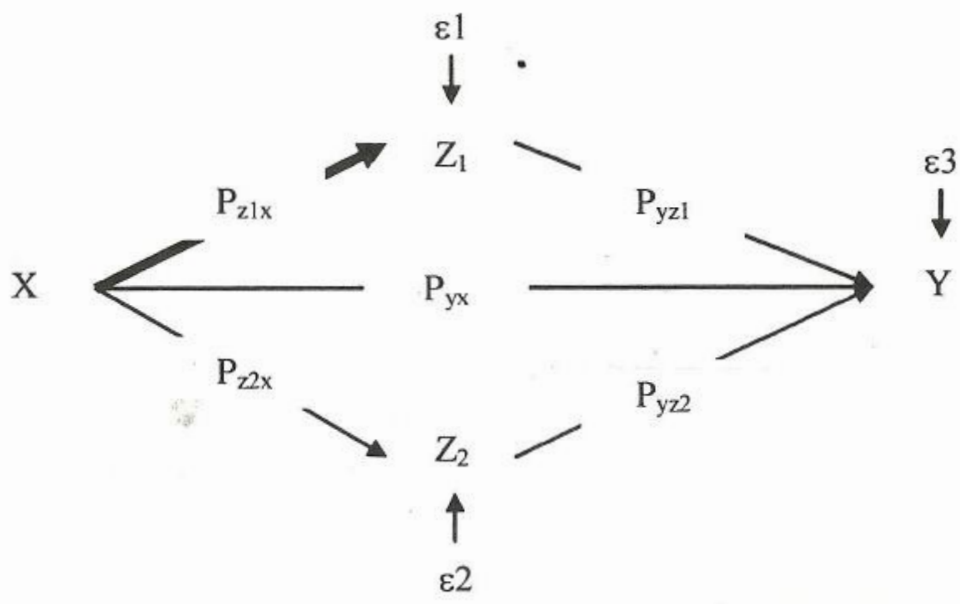

Keterangan:

$\mathrm{X}$ - Intelegensi

Z1 - Kemampuan Menyimak

Z2 - Kemampuan Membaca

$\mathrm{Y}$-Prestasi Belajar

$\varepsilon$-Error

\section{Gambar 1 Analisis Jalur}


intelegensi, yang memiliki nilai dari 1 hingga 5. Nilai 1 berarti di bawah ratarata dan nilai 5 berarti sangat cerdas. Tes APM menunjukan bahwa $50 \%$ responden memiliki nilai 5, dan $37 \%$ responden mendapatkan nilai 4 , serta sisanya $13 \%$ responden memperoleh nilai 3. Tidak ada responden yang memperoleh nilai tes APM di bawah nilai 3. Secara keseluruhan hasil tes tersebut menunjukkan bahwa para responden memiliki nilai intelegensi tinggi.

Kemampuan Menyimak. Tes kemampuan menyimak meliputi enam aspek kognitif hierarkis atau berjenjang mulai dari aspek: ingatan, pemahaman, penerapan, analisis, sintesis dan evaluasi. Responden memperoleh nilai tertinggi 80 untuk aspek sintesis dan nilai terendah 30 untuk aspek evaluasi. Nilai rata-rata responden untuk kemampuan menyimak adalah 57 (Tabel 1).
Kemampuan Membaca. Tes kemampuan membaca pun meliputi enam aspek kognitif hierarki atau berjenjang mulai dari: ingatan, pemahaman, penerapan, analisis, sintesis dan evaluasi. Responden memperoleh nilai tertinggi 83 untuk aspek ingatan, dan nilai terendah 51 untuk aspek analisis. Nilai rata-rata responden untuk kemampuan membaca adalah 67 (Tabel 2).

Prestasi Belajar. Studi ini menggunakan 3 macam pengukuran dalam menilai prestasi belajar, yaitu nilai ujian akhir nasional, nilai ujian akhir sekolah dan rapor kelas III semester 1 dan semester 2 untuk tahun akademik2004/2005. Dari studi ini hanya terdapat 6 responden $(5,4 \%)$ yang memperoleh nilai ujian akhir nasional lebih dari 7. Hampir semua responden $(94,6 \%)$ memperoleh nilai ujian akhir nasional kurang dari 7. Sebanyak 23

Tabel 1

Kemampuan Menyimak Responden Berdasarkan Aspek Kognitif

\begin{tabular}{l|l}
\hline Aspek Kognitif & Skor \\
\hline Ingatan & 60 \\
Pemahaman & 49 \\
Penerapan & 56 \\
Analisis & 69 \\
Sintesis & 80 \\
Evaluasi & 30 \\
Rata-rata kemampuan menyimak & 57 \\
\hline
\end{tabular}


Tabel 2

Kemampuan Membaca Responden Berdasarkan Aspek Kognitif

\begin{tabular}{l|l}
\hline Aspek Kognitif & Nilai \\
\hline Ingatan & 83 \\
Pemahaman & 74 \\
Penerapan & 59 \\
Analisis & 51 \\
Sintesis & 64 \\
Evaluasi & 74 \\
Rata-rata kemampuan membaca & 67 \\
\hline
\end{tabular}

responden $(20,6 \%)$ memperoleh nilai ujian akhir nasional antara 6.0-6.9, 33 responden $(29,5 \%)$ memperoleh nilai ujian akhir nasional antara 5.0-5.9, dan 35 responden $(31,2 \%)$ memperoleh nilai ujian akhir nasional antara 4,04,9 , serta 15 responden memperoleh nilai ujian akhir nasional antara 3,03,9 (dapat dilihat dalam Tabel 3.)

Berdasarkan studi yang telah dilakukan, menunjukkan bahwa sebagian besar responden pada ujian akhir sekolah memperoleh nilai kurang dari 5. Hal tersebut ditunjukkan dengan 45 responden $(40,2 \%)$ męmperoleh nilai ujian akhir sekolah antara 4.0-4.9, dan 15 responden (13.4\%) yang memperoleh nilai ujian akhir sekolah kurang dari 4.0. Dari semuanya, hanya terdapat 6 responden $(5,3 \%)$ yang memperoleh nilai ujian akhir sekolah lebih dari 7. Untuk lebihnya, dapat dilihat dalam Tabel 4.

\section{Tabel 3 Nilai Ujian Akhir Nasional}

\begin{tabular}{l|l|l}
\hline Nilai & Jumlah Responden & Persentase \\
\hline $3.0-3.9$ & 15 & 13.4 \\
$4.0-4.9$ & 35 & 31.2 \\
$5.0-5.9$ & 33 & 29.5 \\
$6.0-6.9$ & 23 & 20.5 \\
$>7.0$ & 6 & 5.4 \\
Total & 112 & 100,0 \\
\hline
\end{tabular}


Tabel 4 Nilai Ujian Akhir Sekolah

\begin{tabular}{l|l|l} 
Nilai & Jumlah Responden & Persentase \\
$3.0=3.9$ & 15 & 13.4 \\
$4.0=4.9$ & 45 & 40.2 \\
$5.0-5.9$ & 17 & 15.2 \\
$6.0-6.9$ & 29 & 25.9 \\
7.0 & 6 & 5.3 \\
Total & 112 & 100,0 \\
\hline
\end{tabular}

Studi ini menemukan pula bahwa 40 responden (35.7\%) mempunyai nilai sangat baik (lebih dari 6) pada raport kelas III tahun ajaran 2004/ 2005. Sebanyak 27 dan 21 responden (48 responden) masing-masing $24,1 \%$ dan $18,8 \%(42.9 \%)$ memperoleh nilai rapor kurang dari 5 . Nilai 5 pada rapor dianggap di bawah standar. Untuk lebih jelasnya, dapat dilihat dalam Tabel 5.

\subsection{Pengaruh Intelegensi terhadap Kemampuan Menyimak dan Kemampuan Menyimak}

Untuk mengukur pengaruh intelegensi terhadap kemampuan menyimak dan kemampuan membaca, studi ini mempergunakan analisis korelasi. Koefisien korelasi antara intelegensi dengan kemampuan menyimak adalah sebesar 0.49 dan antara intelegensi dengan kemampuan membaca adalah 0.63 . Studi ini juga menggunakan t-test. Hasil studi ini menunjukan bahwa intelegensi mempunyai pengaruh yang signifikan baik terhadap kemampuan

\section{Tabel 5 Rapor Kelas III}

\begin{tabular}{l|l|l}
\hline Nilai & Jumlah Responden & Persentase \\
\hline $4.0-4.4$ & 27 & 24.1 \\
$4.5-4.9$ & 21 & 18.8 \\
$5.0-5.4$ & 19 & 17.0 \\
$5.5-5.9$ & 5 & 4.4 \\
$>6.0$ & 40 & 35.7 \\
Total & 112 & 100,0 \\
\hline
\end{tabular}


menyimak maupun terhadap kemampuan membaca dengan tingkat kepercayaan 0.01. Studi ini pun menghitung koefisien determinasi di antara kedua hubungan tersebut. Koefisien determinasi antara intelegensi dengan kemampuan menyimak adalah 0.24 dan antara intelegensi dengan kemampuan membaca adalah 0.40 .

\subsection{Pengaruh Intelegensi, Kemampuan Menyimak dan Kemampuan Membaca terhadap Prestasi Belajar}

Untuk mengukur pengaruh bersama antara intelegensi, kemampuan menyimak dan kemampuan membaca terhadap prestasi belajar, studi ini menggunakan analisis jalur. Dengan menggunakan SPSS (Statistical Package for Social Science 2004), hasil analisis jalur dapat dilihat pada Gambar2.

Hasil analisis jalur yang menunjukkan bahwa kemampuan membaca memiliki koefisien jalur paling tinggi (0.49). Kemampuan menyimak dan kemampuan membaca memiliki koefisien jalur masing-masing sebesar 0.27 dan 0.25 . Hal ini menunjukkan bahwa kemampuan membaca memiliki pengaruh paling tinggi terhadap peningkatan prestasi belajar dibandingkan dengan kemampuan menyimak dan intelegensi.

Studi ini pun menggunakan ttest untuk mengetahui tingkat signifikansi antara hubungan tersebut. Hasil t-test menunjukkan bahwa ketiga hubungan itu intelegensi dengan prestasi belajar, dan kemampuan menyimak dengan prestasi belajar, serta kemampuan membaca dengan prestasi belajar memiliki tingkat signifikansi 0.01 . Hal tersebut menunjukkan bahwa baik intelegensi, kemampuan menyimak dan kemampuan membaca mempunyai pengaruh yang signifikan terhadap prestasi belajar.

Studi ini juga menghitung koefisien determinasi (R2) yang menunjukkan kontribusi keseluruhan dari intelegensi, kemampuan menyimak dan kemampuan membaca terhadap prestasi belajar sebesar 0.69. Hasil tersebut menunjukkan bahwa $69 \%$ peningkatan prestasi belajar dapat dijelaskan dengan pengaruh gabungan antara ingtelegensi, kemampuan membaca dan kemampuan menyimak. 


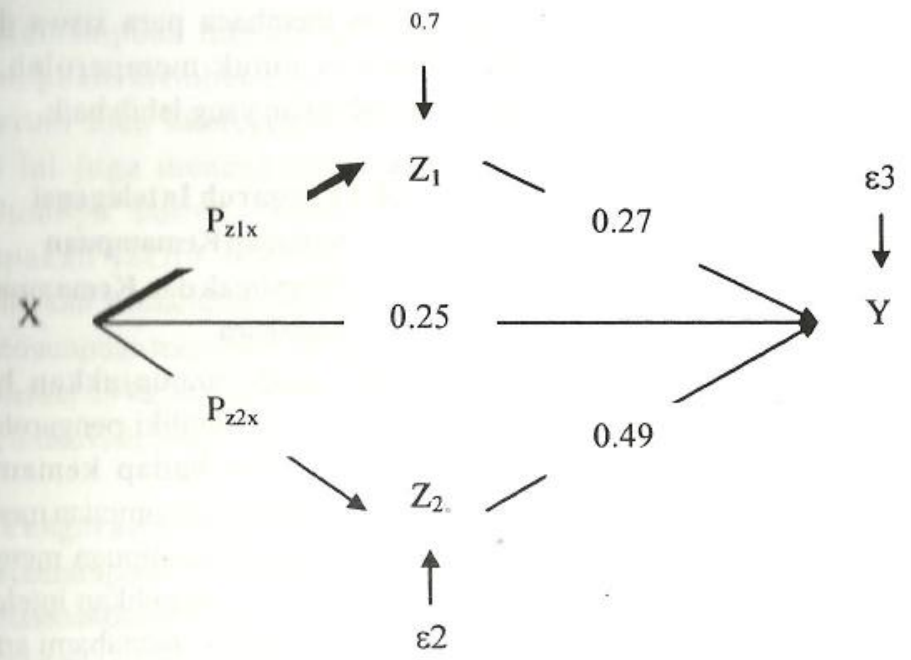

Keterangan:

$\mathrm{X}$-Intelegensi

Z1 - Kemampuan Menyimak

Z2 - Kemampuan Membaca

$\mathrm{Y}$ - Prestasi Belajar

$\varepsilon$ - Error

\section{Gambar 2 Hasil Analisis Jalur}

\subsection{Diskusi}

\subsubsection{Kemampuan Menyimak dan}

\section{Membaca}

Hasil studi menunjukkan bahwa ratarata kemampuan menyimak responden adalah 57 , nilai tersebut dikategorikan cukup/sedang. Terdapat beberapa faktor yang mempengaruhi rendahnya kemampuan menyimak, yaitu faktor internal dan eksternal. Faktor internal bersumber dari penyimak itu sendiri dan faktor ekternal meliputi latihan dan situasi pada saat menyimak. Suhendar dan Supinah (1997 a) berpendapat bahwa faktor latihan memegang peranan penting untuk menghindari gangguan dalam proses menyimak. Faktor situasi meliputi tempat, waktu dan keadaan harus kondusif bagi penyimak untuk berkonsentrasi ketika menyimak (Rost 1990). Namun, 
faktor internallah yang memegang peranan penting dan menentukan dalam keefektifan proses menyimak.

Begitu pula, rata-rata kemampuan membaca responden hanya mencapai skor 67, yang menunjukkan tidak terlalu baik atau rendah. Rendahnya kemampuan membaca tersebut disebabkan oleh beberapa faktor yaitu kurangnya motivasi, rendahnya minat, rendahnya kebiasaan membaca, dan kurangnya keahlian membaca. Untuk meningkatkan keahlian membaca, para siswa dianjurkan untuk lebih sering melakukan latihan (Syaodih dan Surya 1974, Mulyana 2000, Yap 1977, Suhendar dan Pien Supinah 1997 b).

Seperti telah dikemukakan terdahulu, nilai rata-rata kemampuan menyimak dan kemampuan membaca para responden masing-masing sebesar 57 dan 67. Tampak bahwa kemampuan menyimak lebih rendah dibandingkan dengan kemampuan membaca. Fakta tersebut cukuplah beralasan sebab kurikulum Bahasa Indonesia di sekolah kurang memperhatikan kegiatan menyimak jika dibandingkan dengan kegiatan membaca. Karenanya menyimak dan membaca memegang peranan penting di dalam proses belajar mengajar di sekolah sehingga sangat pentinglah kemampuan menyimak dan kemam- puan membaca para siswa ditingkatkan untuk memperoleh hasil pendidikan yang lebih baik.

\subsubsection{Pengaruh Intelegensi terhadap Kemampuan Menyimak dan Kemampuan Membaca}

Hasil studi menunjukkan bahwa intelegensi memiliki pengaruh yang signifikan terhadap kemampuan menyimak dan kemampuan membaca para siswa. Kemampuan menyimak seseorang membutuhkan intelegensi yang baik untuk memahami arti kata yang disampaikan secara oral. Begitu pula dengan kemampuan membaca, kemampuan membaca seseorang membutuhkan intelegensi yang baik untuk memahami tulisan ataupun simbol (The Liang Gie 1994; Suhendar dan Pien Supinah 1997 b). Untuk mengerti sekumpulan huruf dan simbol, seseorang harus mengubahnya menjadi arti kata. Usaha memgubah tersebut berhubungan erat dengan intelegensi.

Kumpulan kata dan simbol merupakan bagian dari bahasa. Bahasa adalah alat berkomunikasi dan berhubungan dengan kemampuan berfikir (Suhendar dan Pien Supinah 1997 b). Kemampuan berfikir didukung oleh intelegensi, sehingga jelas pula bahwa bahasa berhubungan dengan intelegensi. 
Kemampuan menyimak dan Kemampuan membaca jelas dipengaruhi oleh intelegensi. Hasil inadi ini juga mendukung studi bebelumnya bahwa intelegensi merupakan faktor penting yang menentukan kemampuan menyimak dan kemampuan membaca para siswa (Durmeister 1978; Maltin 1994; Strang 1968; Stanovich 1984; Yap 1977).

\subsubsection{Pengaruh Intelegensi, Kemampuan Menyimak dan Kemampuan Membaca terhadap Prestasi Belajar}

Studi ini menemukan pengaruh bersama yang sangat signifikan antara intelegensi, kemampuan menyimak dan kemampuan membaca terhadap prestasi belajar. Hasil tersebut mengindikasikan betapa pentingnya kemampuan menyimak dan kemampuan membaca para siswa serta intelegensi dimilikinya untuk mencapai hasil pendidikan yang lebih baik.

Intelegensi merupakan faktor penting yang menentukan prestasi belajar para siswa, tetapi bukanlah merupakan satu-satunya faktor penentu. Terdapat beberapa faktor lain, yang menentukan prestasi belajar para siswa yaitu kemampuan menyimak dan kemampuan membaca. Kemampuan membaca dan kemam- puan menyimak merupakan faktor penentu keberhasilan siswa di sekolah di samping intelegensi.

Untuk meningkatkan kemampuan menyimak dan kemampuan membaca, para siwa membutuhkan latihan lebih banyak. Siswa yang lebih sering berlatih menyimak dan membaca akan terbiasa untuk menyimak dan membaca. Hasilnya, para siswa akan lebih responsif dalam menjawab pertanyaan-pertanyaan di dalam tes dan akhirnya dapat meningkatkan prestasi belajar para siswa.

Hasil studi ini turut mendukung studi sebelumnya yang menyatakan bahwa intelegensi, kemampuan membaca dan kemampuan menyimak para siswa merupakan faktor penentu prestasi belajar para siswa baik di Amerika Serikat (Vineyard and Bailey 1960; Vineyard and Massey (1957) maupun di Indonesia (Adiwiria 2002; Rosidi 1972; Haryanto 1999).

\section{Simpulan dan Saran}

Studi ini menemukan konsep baru dan model. Konsep baru ditemukannya pengaruh intelegensi, kemampuan menyimak dan kemampuan membaca secara bersamaan terhadap prestasi belajar siswa, dan model merupakan pola pengaruh intelegensi, kemampuan menyimak, 
dan kemampuan membaca serta prestasi belajar. Model tersebut menjelaskan pengaruh intelegensi terhadap menyimak dan membaca, serta pengaruh intelegensi, menyimak dan membaca terhadap prestasi belajar. seperti disajikan dalam Gambar 3. Model tersebut menjelaskan pengaruh intelegensi terhadap kemampuan menyimak dan kemampuan membaca, serta pengaruh gabungan antara intelegensi, kemam- puan menyimak, dan kemampuan membaca terhadap prestasi belajar.

Studi ini menyarankan beberapa kebijakan untuk meningkatkan kualitas pendidikan dan prestasi belajar siswa.

Pemerintah dalam menyusun kurikulum khususnya untuk mata pelajaran bahasa Indonesia hendaknya lebih menekankan pada program latihan dalam mata pelajaran menyimak dan membaca para siswa.

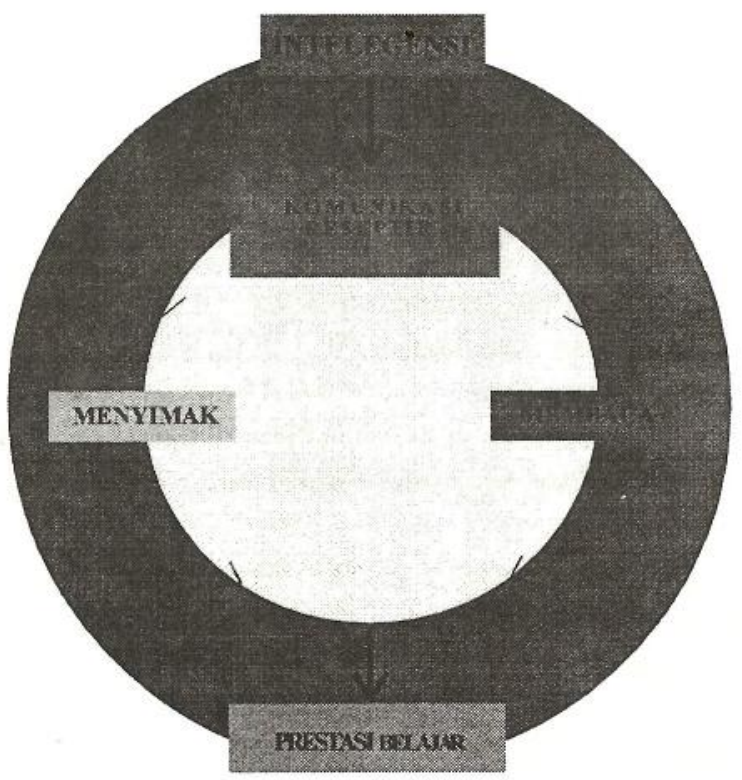

Gambar 3

Model Pengaruh Intelegensi, Kemampuan Menyimak dan Kemampuan Membaca terhadap Prestasi Belajar 
Mengingat kemampuan menyimak din Kemampuan membaca sangat berperan dalam meningkatkan mrestasi belajar siswa. Dengan demikian guru dalam proses репеgjaran di kelas harus banyak memberikan program latihan kepada рага siswa dalam mata pelajaran bahasa Indonesia. Program latihan menyimak dan membaca itu harus ditindaklanjuti dengan aktif respon dari siswa dari apa yang telah disimaknya atau dibacanya. Selain itu, pilak sekolah hendaknya menyediakan fasilitas seperti laboratorium bahasa sebagai sarana untuk melatih kemampuan menyimak, dan perpustakaan sekolah sebagai sarana untuk melatih kemampuan membaca, serta harus didukung juga oleh ruangan yang nyaman untuk kedua keterampilan tersebut. Juga pihak sekolah dan guru hendaknya memberikan budaya gemar menyimak dan membaca pada siswa. Selain pihak sekolah, peran keluarga dan lingkungan amat dibutuhkan dalam membudayakan kebiasaan menyimak dan membaca tersebut.

\section{Pustaka Acuan}

Adiwiria, Pien.S. 2002. Pengaruh Keterampilan Menyimak Sebagai Komunikasi Langsung dan IQ terhadap Prestasi Belajar. Bandung: PPS.

Akil, Mansur. 1993. Beberapa Faktor Yang Mewarnai Kemampuan Membaca. Bandung: UPI

Banks, J. 1985. Teaching Strategies for the Social Studies. New york \& London : Longman.

Barker, L., Edwards, R., Gaines., C., Gladney., K.,\& Holley,F. 1980. An Investigation of Proportional Time Spent in Various Communication Activities by Collega Students. Journal of Applied Communication Research 8, 101-109.

Beery, Althea. 1954. Interrelationships between Listening and Other Language Arts Areas. Elementary English 31: 164-172.

Bloom, B.S. 1974. Taxonomy of Educational Objectives. The Classification of Education Goals. Hand book I Cognitive Domain New York: Longman INC.

Burmeister, L.E. 1978 Reading Strategies for Middle and Secondary School Teachers. California:Addision-Wesley Publishing Company. 
Li, Ching Chun. 1975. Path Analysis-A Primer. California: The Boxwoo press. Doman. 1986. Mengajar Bayi Anda Membaca (terj. Ismail Marahimin). Jakarta: Gaya Favorit Press.

Dwyer, Francis M. 1978. Strategies for Improving Visual Learning. Pensylvania: Learning service.

Haryanto Zeni.1999. Analisis Pola Pikir, Kemampuan membaca Ilmiah dan

Prestasi belajar Fisika Ditinjau dari Aspek perbedaan jenis kelamin. Bandung:PPS

Heryadi, Dedi 2001.Kontribusi Kemampuan Berpikir dan Kemampuan Memahami Makna Kalimat terhadap Kemampuan Menyimak. Bandung:UPI.

Johnson, W.Bouchard, T.J.Segal, N.L., dan Samuel, J.2005. General Intelegence and Reading Performance in Adults. Is Genetic Faktor Structure the Same as for Children? Personality and Individual Differences 38(6): 14131428.

Maltin, Margaret W.1994. Cognition. Rhiladelphia:Harcourt Brace Publishers.

Moegiadi. 1992. Kemampuan Membaca Peserta Didik SD Perlu Ditingkatkan (Orasi Ilmiah Dies Natalis ke-38) Bandung:UPI.

Mulyana, Deddy. 2000. Ilmu Komunikasi: Suatu Pengantar. Bandung: Remaja Rosdakarya

Nichols, Ralph G. 1948. Factors in Listening Comprehension. Speech Monographs 15 (2): 154-163.

Nida, Eugene. 1952. Selective Listening. New York: American Bible Society

Nursaid. 1992. Hubungan antara Kemampuan Operasi Logis dan Penguasaan Struktur Bahasa Indonesia dengan Kemampuan Menyimak. Bandung: PPS.

Razak Abdul. 1989. Pemahaman Bacaan Dihubungkan dengan Kuantitas Pembaca dan Intelegensi. Bandung: FPS.

Rixon, Shelagh. 1981. Developing Listening Skills. London : MacMillan Publisher, $\mathrm{Ltd}$.

Rosidi. 1972. Pembinaan Minat Baca. Jakarta: Balai Pustaka.

Rost,M. 1990. Listening in Language Learning. New York: Longman Group Inc.

Rusyana. 1981. Kemampuan Berbahasa Indonesia Siswa SPG di Jabar Jakarta: Pusat Pembinaan dan Pengembangan Bahasa Indonesia. 
Soegianto, 1981.Kemampuan Berbahasa Madura:Mendengarkan dan Berbicara.

Jakarta : P3B

Strang. 1968. Reading diagnosis and remediation, International Reading Association: Newark: DE

Syaodih\& Surya. 1974. Pengantar Psikologi. Bandung:BP.

Stanovich, A. K.E. Cunningham and D. Freeman, 1984. The relationship between early reading acquisition and word decoding with and without context: A longitudinal study of first-grade children. Journal of Educational Psychology 76:668-677.

Suhendar, \& Pien Supinah.1997a. Bahasa Indonesia: Pengajaran dan Ujian Keterampilan Menyimak dan Keterampilan Berbicara. Bandung: Pionir Jaya

1997b. Pengajaran dan Ujian Keterampilan Membaca dan Keterampilan Menulis. Bandung: Pionir Jaya.

Tampubolon. 1986. Kemampuan Membaca. Bandung:Angkasa.

The Liang Gie. 1994.Cara Belajar yang Efesien 1.Yogyakarta: Liberty

Tubbs, Stewart. 2000. Human Communiction. Bandung :Remaja Rosda Karya Vineyard, Edwin E. dan Massey, Harold W. 1957. The Interrelationship of Certain Linguistic Skills and Their Relationship with Scholastic Achievement when Intelligence is Ruled Constant. The Journal of Educational Psychology 48:279-286.

Vineyard, Edwin E. dan Bailey, Robert B. 1960. Interrelationship of Reading Ability, Listening Skill, Intelligence and Scholastic Achievement. The Journal of Education Reading3: 174-178.

Yap. 1977. Relationships between Amounts of Reading Activity and Reading Achievement. The Journal of Education Reading 17 (1). 